\title{
PROCAMPYLASPIS UNICORNIS SP. NOV., A NEW CUMACEAN CRUSTACEA FROM THE EAST CHINA SEA
}

\author{
AUTHOR(S): \\ Gamo, Sigeo
}

\section{CITATION:}

Gamo, Sigeo. PROCAMPYLASPIS UNICORNIS SP. NOV., A NEW CUMACEAN CRUSTACEA FROM THE EAST CHINA SEA. PUBLICATIONS OF THE SETO MARINE BIOLOGICAL LABORATORY 1977, 24(1-3): 133-139

\section{ISSUE DATE:}

1977-11-30

URL:

http://hdl.handle.net/2433/175954

RIGHT: 


\title{
PROCAMPYLASPIS UNICORNIS SP. NOV., A NEW GUMAGEAN GRUSTAGEA FROM THE EAST GHINA SEA
}

\author{
SIGEO GAMÔ \\ Faculty of Education, Yokohama National University, Yokohama 240
}

With Text-figures 1-3

In the genus Procampylaspis (Nannastacidae) there have been described twelve species (Bonnier, 1896; Calman, 1906; Zimmer, 1907; Stebbing, 1912; Hansen, 1920; Hale, 1945; Reyss et Soyer, 1966; Jones, 1971; Bacescu et Muradian, 1972). All these species have been collected from Atlantic, Mediterranean, Antarctic and South Australian waters. None of the species has been recorded from Northern Pacific waters.

This paper deals with a new species Procampylaspis unicornis, which was collected from off north-west of Miyako-Jima Island, depth about $1700 \mathrm{~m}$, in the East China Sea by beam-trawl during the cruise of R.V. Hakuho-Maru of the Ocean Research Institute, University of Tokyo, in May 1968 (KH-68-2).

The holotype specimen is preserved in the author's collection untill the study is accomplished. After that, in future, the specimen will be transfered for permanent preservation to the National Science Museum, Tokyo.

The author is grateful to Professor Masuoki Horikoshi of the Ocean Research Institute, University of Tokyo, for giving him the opportunity of the study. And also his thanks are due to the stuff members of the R.V. Hakuho-Maru for their much helps for collecting the material during her cruise and other members of the Institute who gave him their kind helps in many ways.

\section{Procampylaspis unicornis sp. nov.}

(Figs. 1-3)

Description: holotype subadult female, length $3.94 \mathrm{~mm}$. The integument is well calcified. There are sparse hairs on the surface of the body integument. The carapace is long pear-like in shape as seen from the dorsal aspect and provided with a horn-like tubercle in the middle of the dorsum. The length of the carapace is a little less than $1 / 2$ of the total body length and slightly more than 1 and $1 / 2$ times as long as wide, which as wide as deep. The antennal notch is very small, but distinctly marked. The lower margin of carapace is a little serrated. The pseudorostral lobes meet in front of the ocular lobe, a little more than 2 times as long as the ocular lobe;

Publ. Seto Mar. Biol. Lab., XXIV (1/3), 133-139, 1977.

(Article 13) 


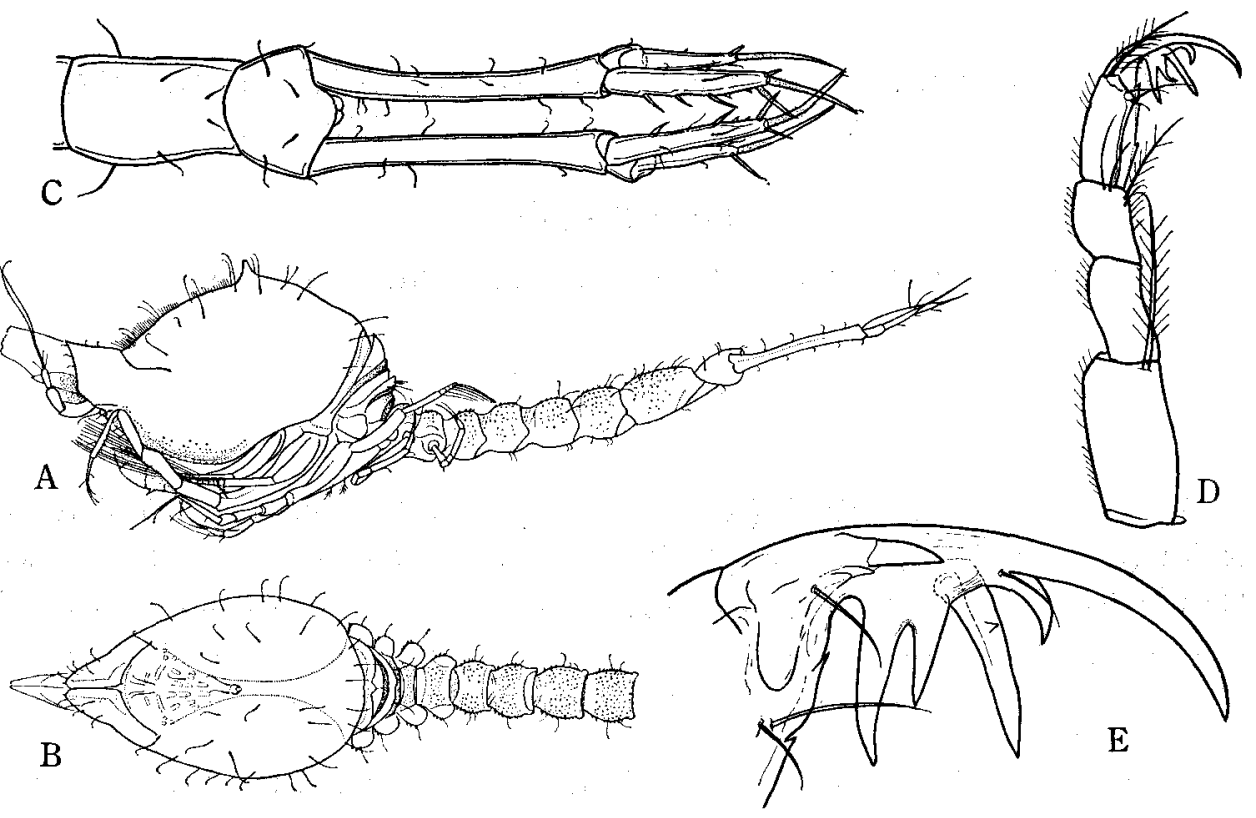

Fig. 1. Procampylaspis unicornis sp. nov., holotype female (length, $3.94 \mathrm{~mm}$ ). A: lateral view. B: anterior portion of body, from above. G: fifth and sixth abdominal segments with uropods. D: second maxilliped. E: dactylus with falciform teeth of second maxilliped.

there is a minute spinules at each apex of the pseudorostral lobes. The ocular lobe is very slender, digitiform and almost inbeded in a median shallow groove between the pseudorostral lobes.

The combinded length of all the free thoracic segments is nearly $1 / 2$ as long as the carapace. The first free thoracic segment is the deepest and widest. The five free thoracic segments are successively decreased in depth and width posteriorly. The fifth is the smallest. The side plates of all the segments are distinct and margined with spinules. The dorsal surface of the posterior two segements are spinulose.

The first peduncular segment of the antennule (Fig. 2, A) is much more than the combined length of the two distal segments. The third segment is much shorter than the second and bears a long main and a minute accessory flagellum. The main flagellum consists of four segments and bears two long aesthetascs on the distal segment; the first segment is very short, about $1 / 10$ as long as the total length of the main flagellum; the third segment is the longest, as long as the first and second combined; the fourth is very minute.

The antenna is as shown in Fig. 2, B.

The mandibles (Fig. 2, G-D) are typical for the genus and furnished with five setae and a lacinia mobilis on the left mandible $(\mathrm{C})$ and six setae on the right (D).

The maxillule and maxilla are as shown in Fig. 2, E-F.

The dactylus of the first maxilliped (Fig. 3, A) is very small, rod-like in shape, and bears two long and a short spines at the apex. There are $12+1$ branchial leaflets on the branchial apparatus. 


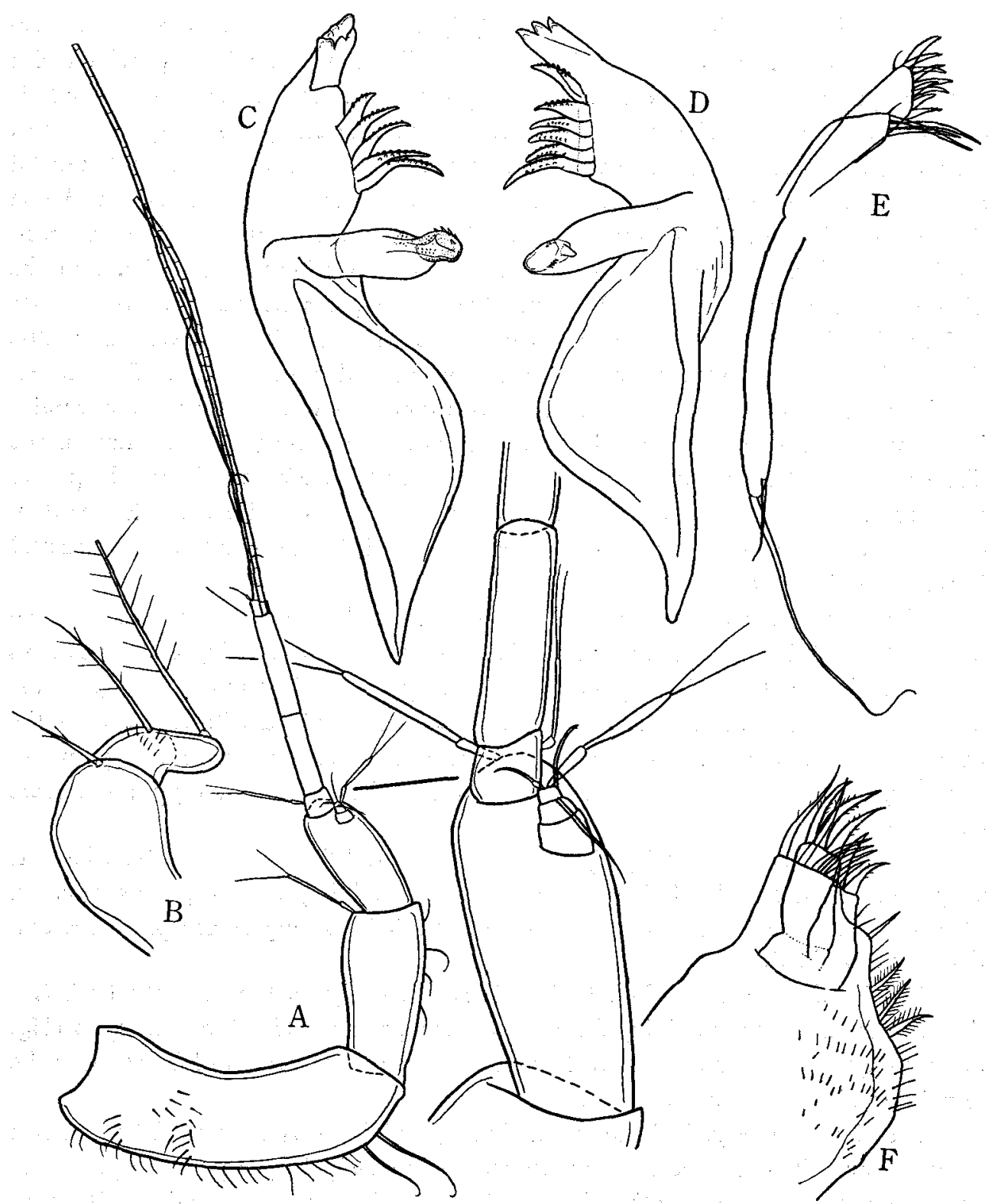

Fig. 2.: Procampylaspis unicornis sp. nov., holotype female. A: antennule. B: antenna. C-D: mandibles. E: maxillule. F: maxilla.

The falciform dactylus of the second maxilliped (Fig. 1, D-E) is very characteristic for the genus and bears four teeth. The distal prolongation of the dactylus is about 3 times as long as rest of the segment. At the base of the main falciform tooth there is a small tooth which is directed distally. The two inner larger teeth are provided with a rather small tooth on each basal portion. The propodus is about subequal to the carpus. 
The basis of the third maxilliped (Fig. 3, B) is nearly as long as the remaining distal segments together; the external distal angle is slightly produced and provided with two long plumose hairs. The ischium is very short and bears a tooth and a fine hair on the inner border. The merus is a little expanded laterally, about $1 / 3$ as long as the basis; there are four teeth on the inner border and one median tooth on the distal end; the external distal produced portion bears two long plumose hairs and one slender curved tooth. The carpus is about $2 / 3$ as long as the ischium and bears hairs on the inner border, two teeth on the outer border and two long plumose hairs on the distal end. The propodus is a little longer than the carpus, serrate on the outer border and furnished with four plumose hairs on the distal end. The dactylus is a little shorter than the propodus, serrate on both borders and bears four long distal setae.

The basis of the first peraeopod (Fig. 3, G) is more than $1 / 2$ as long as the remaining distal segments together and bears two spinules and two plumose hairs on the distal portion. The ischium is about $2 / 5$ as long as the basis and about subequal to the merus. The carpus is slightly shorter than the merus and a little shorter than the propodus. The dactylus is slightly shorter than $1 / 2$ as long as the propodus and bears three distal setae.

The second peracopod (Fig. 3, D) is about 2/3 as long as the total length of the first. The basis is a little longer than $1 / 2$ as long as the remaining distal segments together. The ischium is very short. The carpus is a little more than $1 / 2$ of the combined length of the propodus and dactylus, and provided with two teeth on the external distal angle. The dactylus is about as long as the carpus and propodus together, and bears several setae on the lateral borders and two long plumose setae at the apex.

The third peraeopod (Fig. 3, E) is longer than $1 / 2$ of the first. The basis is very long, about 1 and $1 / 4$ times as long as the remaining distal segments together. The dactylus bears a long sword-like spine, which is as long as the propodus and dactylus combined.

The fourth peraeopod (Fig. 3, F) is shorter than $1 / 2$ of the first; the basis is a little shorter than the remaining distal segments together. The fifth peraeopod (Fig. $3, \mathrm{G})$ is slightly more than $1 / 4$ of the first; the basis is a little less than $1 / 2$ as long as the remaining distal segments together.

The abdomen (Fig. 1, A-C) is less than $1 / 2$ of the body length. The first five segments are about the same in width and successively longer posteriorly. Their dorsal surface is covered with minute spinules and sparse short hairs. The fifth segment is about 1 and $1 / 2$ times as long as the fourth. The sixth segment is about $2 / 3$ as long as and a little wider than the fifth.

The peduncle of the uropod (Fig. 1, G) is 2 and $2 / 3$ times as long as the sixth abdominal segment, and a little less than 3 times as long as the endopod, which is much longer than the exopod. The endopod consists of a single segment, normally has four spines on the inner border and two unequal spines on the apex; there are two spinules on the inner distal border between the third and fourth lateral spines. The exopod is two-segmented and provided with a spine on the outer distal border and 


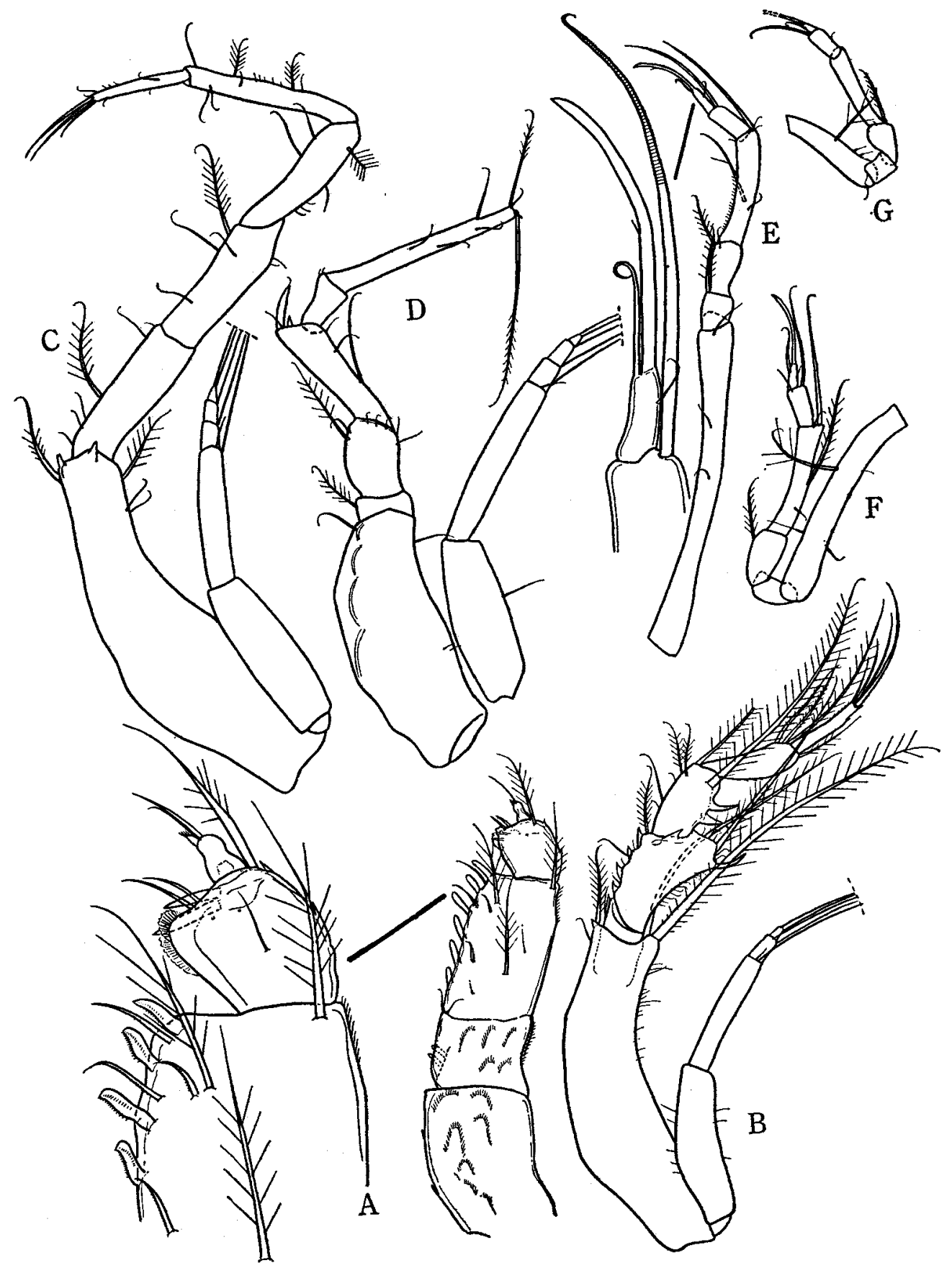

Fig. 3. Procampylaspis unicornis sp. nov., holotype female. A: first maxilliped. B: third maxilliped. G-G: first (G) to fifth (G) peraeopods. 
a long spine at the apex.

Material: 1 i subadult, holotype: St. 13, off north-west of Miyako Jima Island $\left(26^{\circ} 03.6^{\prime} \mathrm{N}, 124^{\circ} 59.1^{\prime} \mathrm{E}\right.$; depth $1700 \mathrm{~m}$, collected by Beam Trawl; 25 May, 1968 (KH 68-2).

Remarks: $P$. unicornis sp. nov. is very alike to $P$. armata Bonnier, 1896 and $P$. sordida Hale, 1945 in having a dorso-median tubercle on the carapace. In the last named two, however, the three inner falciform teeth on the dactylus of the second maxilliped are about subequal in length.

The new species much more resembles P. thalassa Bacescu et Muradian, 1972, but the former is distinguished from the latter by the following characters: 1). The ocular lobe is very small, digitiform and almost imbeded in a shallow groove between the pseudorostral labes (in thalassa the ocular lobe is very salient) 2) The horn-like dorso-median tubercle on the carapace is much salient than that of the latter species. 3) The dorsal surface of the abdominal segments is covered by minute spiniform granules. 4). The propodus of the second maxilliped is slightly longer than the carpus, whereas the latter species has the longer propodus, which is 2 times as long as the carpus. 5) The third maxilliped bears conspicuous spines on the merus and carpus. 6) The first peraeopod with subequal ischium, merus and carpus, whereas thalassa has the ischium about $3 / 4$ as long as the subequal merus and carpus combined. 7) The uropodal peduncle is about 2 and $2 / 3$ times as long as the sixth abdominal segments, while that of thalassa is about 2 times as long as the sixth abdominal segment.

\section{LITERATURE}

Bacescu, M., et Z. Muradian, 1972. Trois nouvelles de Procampylaspis des eaux de la Mauritaine (Atlantique tropical de l'Est)-Rev. Roum. Biol. sér. Zoologie, 17; 3-13.

Bonnier, J., 1896. Edriophthalmes. Rés. Sci. Carnp. du "Caudan"' dans le Golf de Ganscogne. Ann. Univ. Lyon, 24: 527-689, pls. 28-40.

Calman, W.T., 1906. The Cumacea of the Puritan Expedition. Mitt. Zool. Sta. Neapel, 17: 411432.

Fage, L., 1951. Les Gumacé. Faune de France, 54: 1-136. Paul Lechevalier. Paris.

Hansen, H.J., 1920. Crustacea Malacostraca: IV. Daṇish Ingolf Exped, 3: 1 86, 4 pls. Copenhagen.

Hale, H.M., 1945. Australian Cumacea. No. 9. The family Nannastacidae. Res. S. Aust. Mus., 8: 145-218.

Horikoshi, M., S. Gamô, \& M. Imajima, 1971." Benthic communities on the continental shelf in the East China Sea,--Breliminary report on the benthological survey in the Hakuho Maru Cruise KH 68-2. Symposium Geological Problems of the Sea around Kyûshû.

Jones, N.S., 1969. The systematics and distribution of Cumacea from depths exceeding 200 meters. Galathea Rep., 10: 9-180.

1971. Cumacea: The fauna of the Ross Sea. Part 8. Bull. N.Z. Dept. Sci. industr. Res., 206 (N.Z. Oceanogr. Inst. Mem., no. 59): 33-41.

Lomakina, N.B., 1958. Cumacea of the Seas of U.S.S.R., 1-310, U.S.S.R. Acad. Sci. Publ. House, Moscow. (In Russian).

Reyss, D., \& Soyer, J., 1966. Cumacés récueillis lors de la Campagne de la Calypso à Port-Vendres en août-septembre 1964. Bull. Inst. Océanogr., Monaco. 1966. 66, no. 1372 (Trav. Lab. Arago, N.S., $8(26)$ ) : 1-11. 
Stebbing, T.R.R., 1912. The Sympoda. Ann. S. Afr. Mus., 10: 129-176.

1913. Cumacea (Sympoda). Das Tierreich. 39: i-xvi, 1-210. Berlin.

Zimmer, C., 1907. Neue Gumaceen von der Deutschen und Schwedischen Südpolar Expedition aus den Familien der Cumiden, Vaunthompsoniiden, Nannastaciden und Lampropiden. Zool. Anz., $31: 367-374$.

1940. Die Verbreitung der Cumeceen. Arch. Naturg., (2) 9: 224-313.

1941. Cumacea: Bronn's Klassen u. Ordnungen des Tierreich. 5 (1): 1-222. Akad. Verlangs, Leipzig. 